\title{
ASSESSMENT OF INDOOR AIR QUALITY IN AN AUTOMOBILE INDUSTRY
}

\author{
M.Arunkumar ${ }^{1}$, K.Visagavel ${ }^{2}$, H.AbdulZubar ${ }^{3}$ \\ ${ }^{1}$ Student, Mechanical Engineering, Knowledge Institute of Technology, Tamil Nadu, India \\ ${ }^{2}$ Head of the Department, Mechanical Engineering, Knowledge Institute of Technology, Tamil Nadu, India \\ ${ }^{3}$ Associate Professor, Mechanical Engineering, Knowledge Institute of Technology, Tamil Nadu, India
}

\begin{abstract}
This paper investigates the concentration of pollutants like Total Aerosol Mass, Respirable Aerosol Mass, Sulphur dioxide $\left(\mathrm{SO}_{2}\right)$, Nitrogen dioxide $\left(\mathrm{NO}_{2}\right)$ and Carbon Monoxide (CO) generated from various workplaces in the industry. The rate of emissions were collected over a successive periods of about 8 hour at each workplace by using High Volume Sampler and the concentration of these gases in the indoor air is measured. The results will show the concentration of emissions of dust and fumes in the above workplace and suspended solid pollutants will be compared with the permissible limits as per the standards given by OSHA for an industrial area. The main aim of this paper is to identify the contaminated indoor air in the workplace which reflects advisedly towards Environment, Health \& Safety related issues to the workers who were deployed to work in that area through Inhalation, Absorption and Ingestion.
\end{abstract}

Keywords: Indoor air quality, Particulate matter, High volume sampler, OSHA standard limits. $* * *$

\section{INTRODUCTION}

Indoor air quality is an important factor to be considered in an automobile industry. Due to various gases generated during the process, gases mixes with air and gets contaminated. This contaminated air affects the health of the workers who were deployed to work in that area. These gases enter through inhalation, absorption and ingestion of workers and cause Occupational health disease. Awareness of air contaminants and the measures to monitor and control the indoor air quality are inadequate considering the rapid increase in the contamination levels. This is done to prevent the workers from ill health due to air contaminants present in the workplace.

Patterson \&Eatough [6],Gauvin [4] et al., 2002 described that the indoor pollution sources that release gases or particles into the air are the primary cause of indoor air quality problems in homes. Offices inadequate ventilation can increase indoor pollutant levels by not bringing in enough outdoor air to dilute emissions from indoors sources and by not carrying indoor air pollutants out of the home or office. High temperature and humidity levels can also increase concentration of some pollutants. (As cited in [3]).

\subsection{Air Pollution and Indoor Air Quality}

In any atmospheric condition in which certain substances are present in such concentration that they can produce undesirable effects on man and his environment. These contaminants will affect the living beings and cause ill effects to the health. The quality of indoor air inside offices, schools, and workplaces is important not only for the workers comfort but also for their health. Poor indoor air quality has been tied to symptoms like headaches, fatigue, trouble concentrating, and irritation of the eyes, nose, throat and lungs. The factors that affect indoor air quality includes poor ventilation (lack of outside air), problems controlling temperature, high or low humidity, recent remodeling, and other activities in or near a building that can affect the fresh air coming into the building. Sometimes, specific contaminants like dust from construction or renovation, mold, cleaning supplies, pesticides, or other airborne chemicals (including small amounts ofchemicals released as a gas over time) may cause poor In-house ambient air quality.

\subsection{Hazards due to Various Gases Present}

Suspended \&Respirable particulate matter which is the sources form paints, cleaning compounds causes Dizziness, headache, fatigue and affects the eye, respiratory tract and mucous membrane. Carbon monoxide which is the sources from fuel engine exhausts causes dizziness, nausea, cyanosis, headache and fatigue.

Air pollution harms every living being, more so the human population and in particular target severely the occupational groups like car drivers, traffic police personnel, parking lot attendants, tunnel workers, road side vendors, owners and employees of uncovered or frequently open commercial establishments in traffic dense and narrow locations, and all users of public places like bus stands, workshops and cinema theaters. The ill effects on health are severe with the fetus, children, and elders and cardiovascular and angina pectoris patients [1].Also it affects the functioning of heart and brain. At high concentration the impact is fatal. Nitrogen dioxide which is the sources from welding, gas cutting and petrol-engine exhausts causes emphysema, lung irritation, pneumonia, pulmonary edema, asthma, bronchitis, 
respiratory infections. Sulfur dioxide which is the sources from combustion products causes reduced atmosphere visibility, acid rain and sulfurous smog and also affects the respiratory system and human lungs.

\section{EXPERIMENTAL PROCEDURE}

\subsection{Study area}

The automobile industry has a good organization structure manned by qualified and efficient officers. The industry has a good layout of plant and machinery. It has the accomplishment of ISO 9001 Certification. It has the man power strength of Management Staff (329), Workmen (189), Trainees (961), Contract / Casuals (472). In this industry it has the various areas like fuel tank cell, shot blasting, PTCED, liquid painting, paint shop dynamometer testing, Internal logistics Centre, dispatch area.

\subsection{Description of Sampling Sites}

Five sites (fuel tank cell, shot blasting, liquid painting, PTCED, dynamometer testing) were selected for the Indoor Air Quality monitoring in automobile industry. The selected sites were monitored with the help of High volume sampler and the deviation will be compared with the permissible limits as per the standards given by OSHA for an industrial area. A continuous sampling has been carried out for all the sites.

\subsubsection{Fuel Tank Cell}

Fuel tank assembly is made by using power press. Initially the tank material is made by spot welding followed by steam welding. The roll forming machines will perform the rolling of welded tank material parts. The black marks present in the tank are removed by the Finishing machine. Finally the tank is made with the shining surface in the buffing booth.

\subsubsection{Shot Blasting}

Shot blasting consists of attacking the surface of a material with one of many types of shots. It is done to remove something on the surface. Shots are of small size steel balls of various diameters. The device that throws the shots is large air gun and spinning paddles which hurl the shot off their blades.

\subsubsection{PT-CED (Pre-treatment and Cathode Electric}

\section{Deposition)}

The sheet metal fabricated items in the form of frames, petrol tanks, mudguards, tool box are received and stored in ILC (Internal logistic centre). After inspection they will be moved to PRE-TREATMENT plant. The pre-treatment process comprises of de-greasing, de-rusting, and pyro phosphate with water rinses in between stages. This is done with the transportation system. The heating of the solution in this heat exchange is done by thermic fluid circulation.

\subsubsection{Liquid Painting}

The pre-treated parts are loaded in conveyor. It will be cleaned by tack-rags and following by primer coating, color coating, lacquer coating. After that the parts will be moved into oven and the paint is dried. The painted parts will be inspected and moved to vehicle assembly.

\subsubsection{Dynamometer Testing}

The dynamometer test is done for the performance and durability for the disks brake system. The brake dynamometer is to be capable of achieving the stability to ensure and accuracy of plus one percentage of the test speed. The test speed shall be measured as the number of revolutions of the dynamometer shaft that corresponds to the vehicle speed, considering the static load. The system is capable of monitoring following parameters:

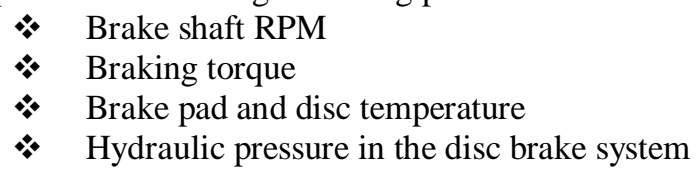

\section{APPARATUS AND METHODS}

Suspended particulate matter concentrations are measured by finding the air volume sample $\left(\mathrm{m}^{3}\right)$ through gravimetric method collected in filter paper. The sulphur dioxide concentration in the In-house ambient air is collected with the help of an appropriate cyclonic particle fractioning device by colorimetric method. Ambient sulphur dioxides are collected by bubbling air through a solution of TCM (TetraChloroMercurate) solution. The nitrogen dioxide concentration in the In-house ambient air is collected with the help of an appropriate cyclonic particle fractioning device by colorimetric method using a solution of sodium hydroxide and sodium arsenite. The carbon monoxide concentration in the In-house ambient air is collected by indicator tube method. In this carbon monoxide reduces yellow silicomolybate to lower oxides.

\subsection{Suspended Particulate Matter}

The suspended matter in ambient air is collected by high volume sampler device by gravimetric method. As the air passes through the cyclone-coarse, non respirable dust is separated from the air stream by centrifugal forces acting on the solid particles and the dust forming is carried by the air stream to the sampling bottle. This gives the measure of suspended particulate matter. The essential features of a typical cyclonic fractioning sampler for suspended particulate matter are those of a compact unit consisting of protective housing blower, voltage stabilizer, time totalizer, rotameter and filter holder capable of supporting a $20.3 \mathrm{~cm} \mathrm{x}$ $25.4 \mathrm{~cm}$ glass fibre filter. It has analytical balance having a sensitivity of $0.01 \mathrm{mg}$ and sampling bottles. Sampling bottle should be conditioned at a constant temperature, 50\% relative humidity and weigh the sampling bottle to the nearest milligrams. Excessively windy and wet should be avoided when changing the samples. Set the timer for the required period of sampling. Run the machine for the required period of time and measure the initial flow rate. 
After sampling is complete, the final flow rate is recorded and the sampling bottle is removed. Weigh the sample collected filter after conditioning as above said (Balashanmugam et al., 2012).

\subsection{Respirable Particulate Matter}

The respirable particulate matter concentration in the ambient air is collected by high volume sampler by gravimetric method. As the air passes through the cyclone coarse, non respirable dust is separated from the air stream by centrifugal force acting on the solid particles and the fine dust forming respirable fraction is carried by the air stream to the filter paper. This gives the measure of respirable particulate matter. The essential features of a typical cyclonic fractioning sampler for respirable particulate matter are those of a compact unit consisting of protective housing blower, voltage stabilizer, time totalizer, rotameter, and filter holder capable of supporting a $20.3 \mathrm{~cm}$ x $25.4 \mathrm{~cm}$ glass fibre filter. It has analytical balance having a sensitivity of $0.01 \mathrm{mg}$. GF - sheets should be conditioned at a constant temperature and $50 \%$ relative humidity and weigh the filters to the nearest milligrams. Loosen the faceplate wing nuts and remove the face plate. Remove the filter from its jacket and center it on the support screen with the rough side of the filter facing upwards. Excessively windy and wet should be avoided when changing the samples. Run the machine for the required period of time and measure the initial flow rate. After sampling is completed the final flow rate is recorded. Weigh the sample collected filter after conditioning as above said (Balashanmugamet al, 2012).

\subsection{Sulphur Dioxide}

The sulphur dioxide concentration in the ambient air is collected with the help of high volume sampler device by colorimetric method. Ambient sulphur dioxides are collected by bubbling air through a solution of $30 \%$ tetrachloromercurate solution at a flow rate of 0.2 LPM for 8 hour.. The concentration of sulphur dioxide ion produced during sampling is determined calorimetrically and concentrations of pararosaniline and formaldehyde solution are added.The essential features of a typical cyclonic fractioning sampler for respirable particulate matter are those of a compact unit consisting of protective housing blower, voltage stabilizer, time totalizer, rotameter and filter holder capable of supporting a $20.3 \mathrm{~cm}$ x $25.4 \mathrm{~cm}$ glass fibre filter (Balashanmugamet al, 2012).

\subsection{Nitrogen Dioxide}

The nitrogen dioxide concentration in the ambient air is collected with the help of a high volume sampler device by colorimetric method. Ambient nitrogen dioxides are collected by bubbling air through a $30 \mathrm{ml}$ solution of sodium hydroxide and sodium arsenite at a flow rate of 1 LPM for 8 hour. The concentration of nitride ion produced during sampling is determined calorimetricallyreacting the nitride ion with phosphoric acid, sulphilamide and NEDA solution for producing azo-dye. The essential features of a typical cyclonic fractioning sample for respirable particulate matter are those of a compact unit consisting protective housing blower, voltage Stabilizer, time totalizer, rotameter and filter holder.

\subsection{Carbon Monoxide}

Ambient air continuously drawn into $250 \mathrm{ml}$ of the sample at the prescribed rate $(40-50 \mathrm{ml} / \mathrm{min})$ through the tube by the aspirator provided. Compare the colour produced with the standard colours provided and calculate the concentrations. The carbon monoxide concentration in the ambient are collected with the help of indicator tube method. Carbon monoxide reduces yellow silicomolybate to lower oxides. The colour changesfrom yellowish green to finally deep blue depending on the extent of reduction which again under identical conditions of carbon monoxide in air. The apparatus used is uniphosphorus.

\section{RESULTS AND DISCUSSION}

The values are not shown as the contaminant levels presentin PTCED are under the permissible limits as per the standards of OSHA.

\subsection{OSHA Standard Limits}

Table 4.1 illustrates the permissible limits as per the standards given by OSHA for an industrial area. These standards are further compared with contaminant levels taken in the various workplaces.

\subsection{Liquid Painting Area}

Table 4.2 and Chart 4.1 illustrate the contaminant levels at the sampled sites for Liquid Painting area during the month of February 2014. In this area, Total aerosol mass and Respirable aerosol mass have crossed the OSHA standard limits.

\subsection{Shot Blasting Area}

Table 4.3 and Chart 4.2 illustrate the contaminant levels at the sampled sites for Shot Blasting area during the month of February 2014. In this area, Total aerosol mass, Respirable aerosol mass and Nitrogen dioxide have crossed the OSHA standard limits.

\subsection{Dynamometer Testing Area}

Table 4.4 and Chart 4.3 illustrate the contaminant levels at the sampled sites for Dynamometer Testing area during the month of February 2014. In this area, Total aerosol mass, Respirable aerosol mass and Nitrogen dioxide have crossed the OSHA standard limits.

\subsection{Fuel Tank Cell Area}

Table 4.5 and Chart 4.4 illustrate the contaminant levels at the sampled sites for Fuel tank cell area during the month of February 2014. In this area, Total aerosol mass, Respirable aerosol mass and Nitrogen dioxide have crossed the OSHA standard limits 


\subsection{Comparison of Contaminants Level with Oshastandard Limits}

Table 4.6 and Chart 4.5 illustrate the comparison of parameters at different workplaces with OSHA standards

Table-1: OSHA Standard limits for test parameters

\begin{tabular}{|l|l|l|}
\hline S.NO & Test parameters & OSHA standard limits \\
\hline 1 & Total aerosol mass & $15 \mathrm{mg} / \mathrm{m}^{3}$ \\
\hline 2 & Respirable aerosol mass & $5 \mathrm{mg} / \mathrm{m}^{3}$ \\
\hline 3 & Sulphur dioxide $\left(\mathrm{SO}_{2}\right)$ & $5 \mathrm{PPM}$ \\
\hline 4 & Nitrogen dioxide $\left(\mathrm{NO}_{2}\right)$ & $5 \mathrm{PPM}$ \\
\hline 5 & Carbon monoxide $(\mathrm{CO})$ & $50 \mathrm{PPM}$ \\
\hline 6 & Oxygen $\left(\mathrm{O}_{2}\right)$ & $19.5 \%$ minimum \\
\hline
\end{tabular}

Table-2: Contaminant level in Liquid painting area

\begin{tabular}{|l|l|l|l|}
\hline S.NO & Test parameters & Results & OSHA standard limits \\
\hline 1 & Total aerosol mass & $15.7 \mathrm{mg} / \mathrm{m}^{3}$ & $15 \mathrm{mg} / \mathrm{m}^{3}$ \\
\hline 2 & Respirable aerosol mass & $6.5 \mathrm{mg} / \mathrm{m}^{3}$ & $5 \mathrm{mg} / \mathrm{m}^{3}$ \\
\hline 3 & Sulphur dioxide $\left(\mathrm{SO}_{2}\right)$ & BDL $(\mathrm{DL}: 0.002 \mathrm{PPM})$ & $5 \mathrm{PPM}$ \\
\hline 4 & Nitrogen dioxide $\left(\mathrm{NO}_{2}\right)$ & $2.50 \mathrm{PPM}$ & $5 \mathrm{PPM}$ \\
\hline 5 & Carbon monoxide $(\mathrm{CO})$ & BDL $(\mathrm{DL}: 0.97 \mathrm{PPM})$ & $50 \mathrm{PPM}$ \\
\hline 6 & Oxygen $\left(\mathrm{O}_{2}\right)$ & $21.0 \%$ & $19.5 \%$ minimum \\
\hline
\end{tabular}

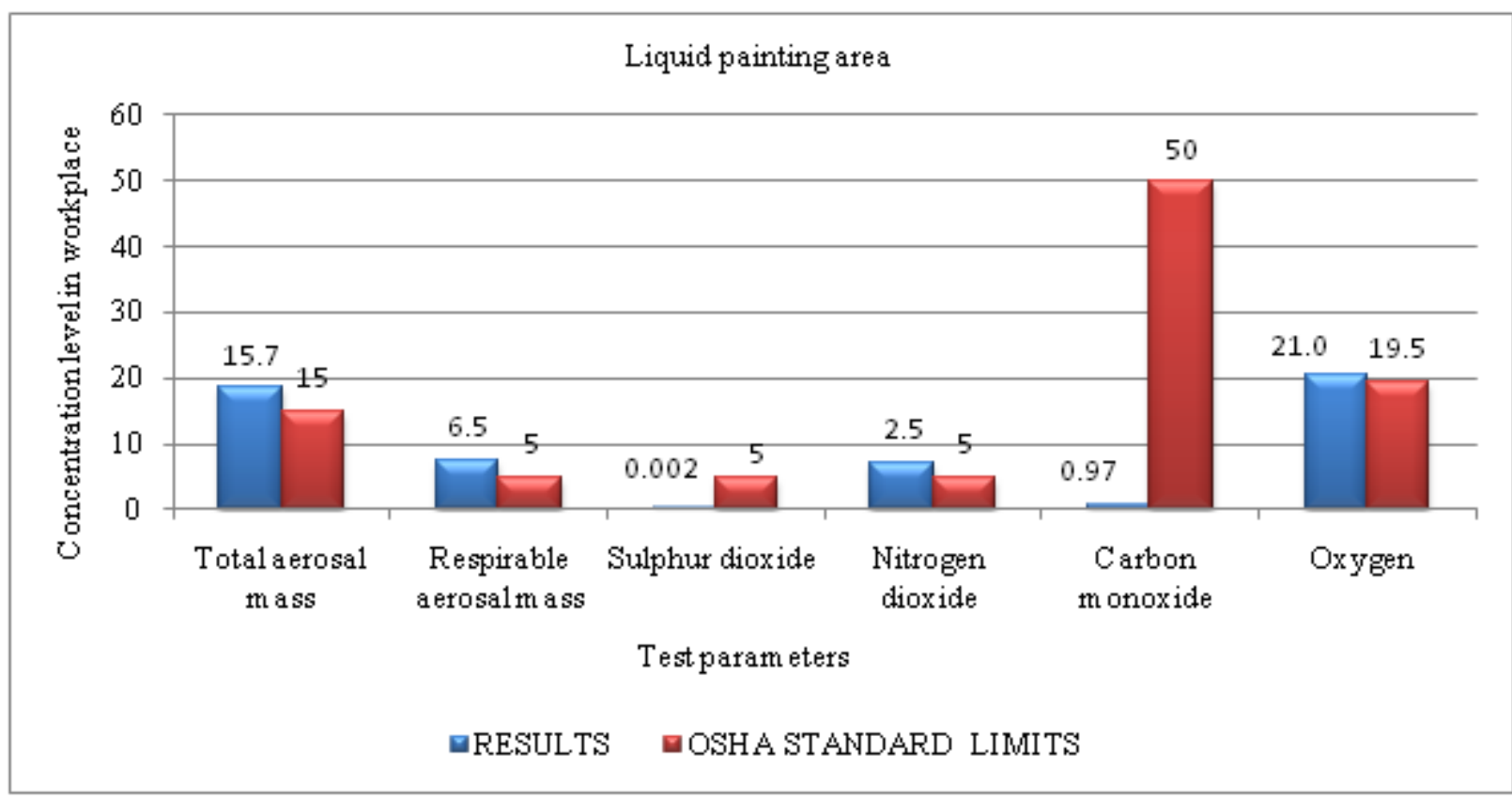

Chart-1: Liquid painting area

From the above observation, Total aerosol mass, Respirable aerosol mass levels have been exceeded when compared with OSHA standards.

Table-3: Contaminant level in Shot blasting area

\begin{tabular}{|l|l|l|l|}
\hline S.NO & Test parameters & Results & OSHA standard limits \\
\hline 1 & Total aerosol mass & $17.3 \mathrm{mg} / \mathrm{m}^{3}$ & $15 \mathrm{mg} / \mathrm{m}^{3}$ \\
\hline 2 & Respirable aerosol mass & $6.7 \mathrm{mg} / \mathrm{m}^{3}$ & $5 \mathrm{mg} / \mathrm{m}^{3}$ \\
\hline 3 & Sulphur dioxide $\left(\mathrm{SO}_{2}\right)$ & BDL (DL:0.002 PPM) & $5 \mathrm{PPM}$ \\
\hline 4 & Nitrogen dioxide $\left(\mathrm{NO}_{2}\right)$ & $6.5 \mathrm{PPM}$ & $5 \mathrm{PPM}$ \\
\hline 5 & Carbon monoxide $(\mathrm{CO})$ & BDL (DL:0.75 PPM) & $50 \mathrm{PPM}$ \\
\hline 6 & Oxygen $\left(\mathrm{O}_{2}\right)$ & $21.4 \%$ & $19.5 \%$ minimum \\
\hline
\end{tabular}




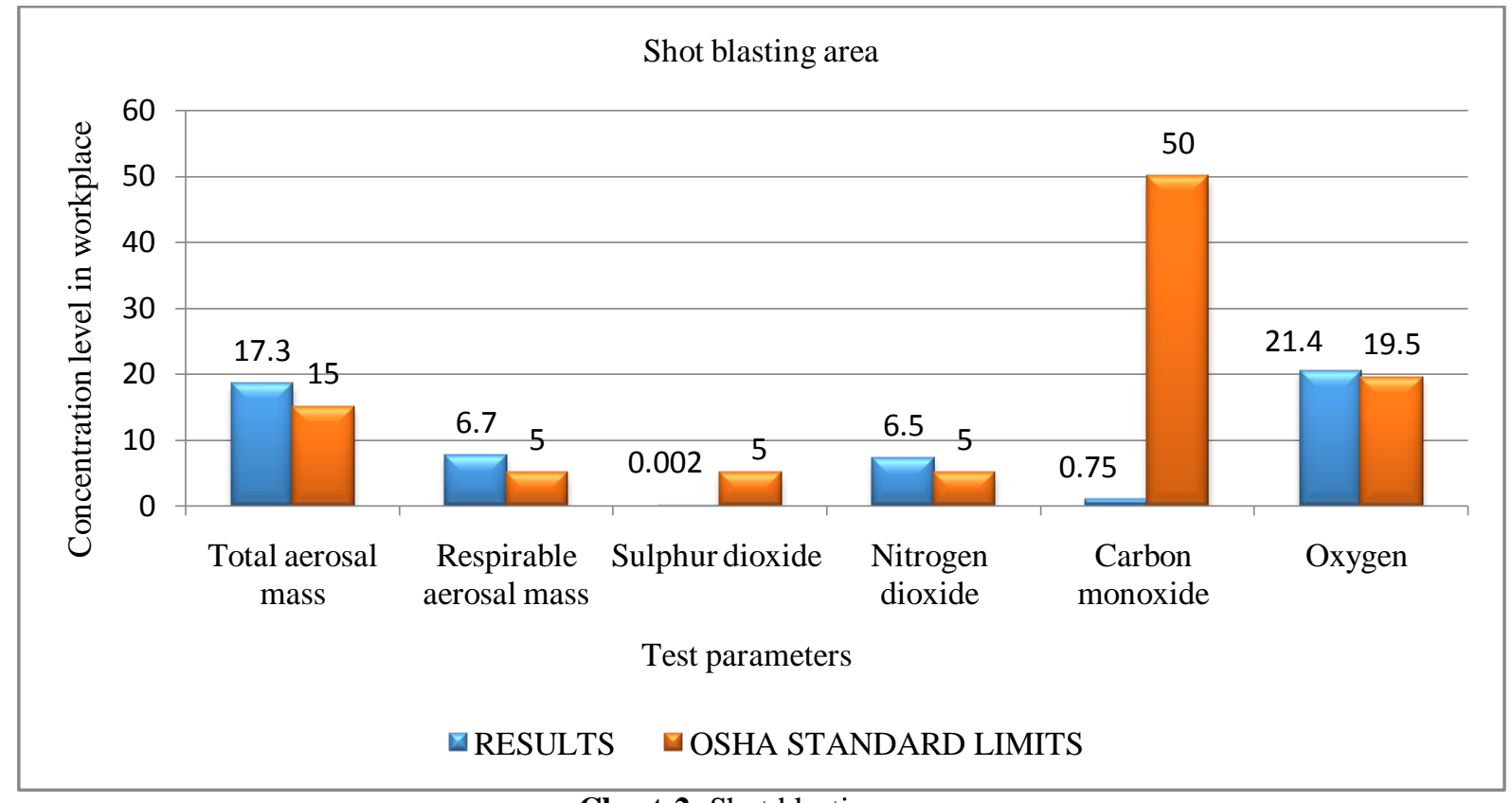

Chart-2: Shot blasting area

From the above observation, Total aerosol mass, Respirable aerosol mass and $\mathrm{NO}_{2}$ levels have been exceeded when compared with OSHA standards.

Table-4:Contaminant level in Dynamometer testing area

\begin{tabular}{|l|l|l|l|}
\hline S.NO & Test parameters & Results & OSHA limits \\
\hline 1 & Total aerosol mass & $16.7 \mathrm{mg} / \mathrm{m}^{3}$ & $15 \mathrm{mg} / \mathrm{m}^{3}$ \\
\hline 2 & Respirable aerosol mass & $6.1 \mathrm{mg} / \mathrm{m}^{3}$ & $5 \mathrm{mg} / \mathrm{m}^{3}$ \\
\hline 3 & Sulphur dioxide $\left(\mathrm{SO}_{2}\right)$ & BDL (DL:0.002 PPM) & $5 \mathrm{PPM}$ \\
\hline 4 & Nitrogen dioxide $\left(\mathrm{NO}_{2}\right)$ & $6.3 \mathrm{PPM}$ & $5 \mathrm{PPM}$ \\
\hline 5 & Carbon monoxide $(\mathrm{CO})$ & BDL $(\mathrm{DL}: 0.97 \mathrm{PPM})$ & $50 \mathrm{PPM}$ \\
\hline 6 & Oxygen $\left(\mathrm{O}_{2}\right)$ & $20.4 \%$ & $19.5 \%$ minimum \\
\hline
\end{tabular}

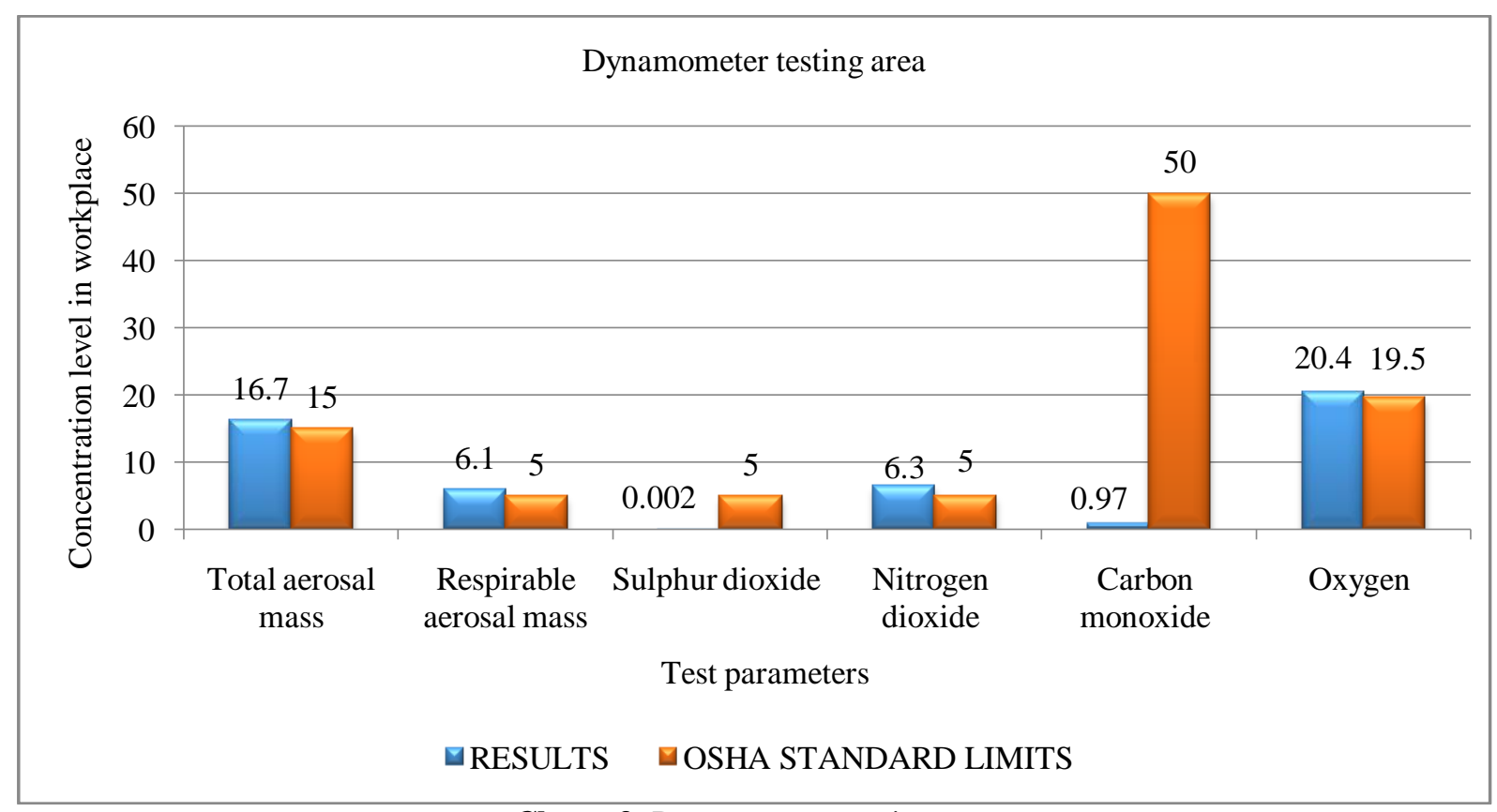

Chart -3: Dynamometer testing area

From the above observation, Total aerosol mass, Respirable aerosol mass and Nitrogen dioxide have been exceeded when compared with OSHA standards. 
Table-5: Contaminant level in Fuel tank cell area

\begin{tabular}{|l|l|l|l|}
\hline S.NO & Test parameters & Results & OSHA limits \\
\hline 1 & Total aerosol mass & $16.9 \mathrm{mg} / \mathrm{m}^{3}$ & $15 \mathrm{mg} / \mathrm{m}^{3}$ \\
\hline 2 & Respirable aerosol mass & $6.55 \mathrm{mg} / \mathrm{m}^{3}$ & $5 \mathrm{mg} / \mathrm{m}^{3}$ \\
\hline 3 & Sulphur dioxide $\left(\mathrm{SO}_{2}\right)$ & BDL (DL:0.002 PPM) & $5 \mathrm{PPM}$ \\
\hline 4 & Nitrogen dioxide $\left(\mathrm{NO}_{2}\right)$ & $7.66 \mathrm{PPM}$ & $5 \mathrm{PPM}$ \\
\hline 5 & Carbon monoxide $(\mathrm{CO})$ & BDL (DL:0.89 PPM) & $50 \mathrm{PPM}$ \\
\hline 6 & Oxygen $\left(\mathrm{O}_{2}\right)$ & $20.0 \%$ & $19.5 \%$ minimum \\
\hline
\end{tabular}

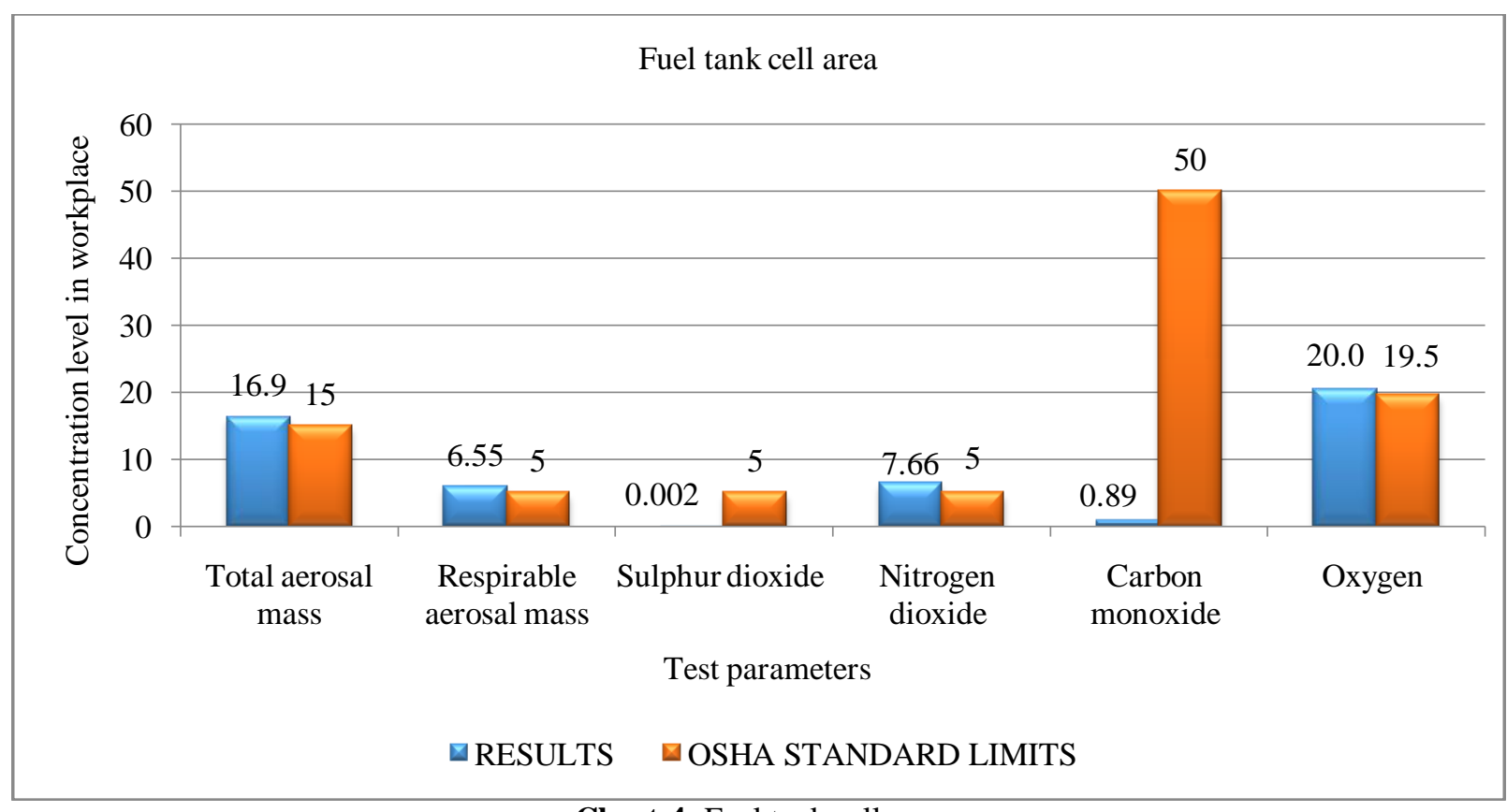

Chart-4: Fuel tank cell area

From the above observation, Total aerosol mass, Respirable aerosol mass and Nitrogen dioxide have been exceeded when compared with OSHA standards.

Table-6: Comparison of parameters at different workplaces with OSHA standards

\begin{tabular}{|l|l|l|l|l|l|l|}
\hline S.NO & Test parameters & $\begin{array}{l}\text { OSHA } \\
\text { standard } \\
\text { limits }\end{array}$ & $\begin{array}{l}\text { Liquid } \\
\text { painting area } \\
\text { area }\end{array}$ & $\begin{array}{l}\text { Shot blasting } \\
\text { Dynamometer } \\
\text { testing area }\end{array}$ & $\begin{array}{l}\text { Fuel } \\
\text { cell area }\end{array}$ \\
\hline 1 & $\begin{array}{l}\text { Total aerosol mass } \\
\left(\mathrm{mg} / \mathrm{m}^{3}\right)\end{array}$ & 15 & 15.7 & 17.3 & 16.7 \\
\hline 2 & $\begin{array}{l}\text { Respirable aerosol mass } \\
\left(\mathrm{mg} / \mathrm{m}^{3}\right)\end{array}$ & 5 & 6.5 & 6.7 & 6.1 & 16.9 \\
\hline 3 & $\begin{array}{l}\text { Sulphur dioxide }\left(\mathrm{SO}_{2}\right) \\
(\mathrm{PPM})\end{array}$ & 5 & $\begin{array}{l}\text { BDL } \\
(\mathrm{DL}: 0.002)\end{array}$ & $\begin{array}{l}\text { BDL } \\
(\mathrm{DL}: 0.02)\end{array}$ & $\begin{array}{l}\text { BDL } \\
(\mathrm{DL}: 0.002)\end{array}$ & $\begin{array}{l}\text { BDL } \\
(\mathrm{DL}: 0.002)\end{array}$ \\
\hline 4 & $\begin{array}{l}\text { Nitrogen dioxide }\left(\mathrm{NO}_{2}\right) \\
(\mathrm{PPM})\end{array}$ & 5 & 2.50 & 6.5 & 6.3 \\
\hline 5 & $\begin{array}{l}\text { Carbon monoxide }(\mathrm{CO}) \\
(\mathrm{PPM})\end{array}$ & 50 & $\begin{array}{l}\text { BDL } \\
(\mathrm{DL}: 0.97)\end{array}$ & BDL (DL:0.75) & $\begin{array}{l}\text { BDL } \\
(\mathrm{DL}: 0.97)\end{array}$ & $\begin{array}{l}\text { BDL } \\
(\mathrm{DL}: 0.89)\end{array}$ \\
\hline 6 & $\begin{array}{l}\text { Oxygen }\left(\mathrm{O}_{2}\right) \\
19.5 \%\end{array}$ & $21.0 \%$ & $21.4 \%$ & $20.4 \%$ & $20.0 \%$ \\
\hline
\end{tabular}




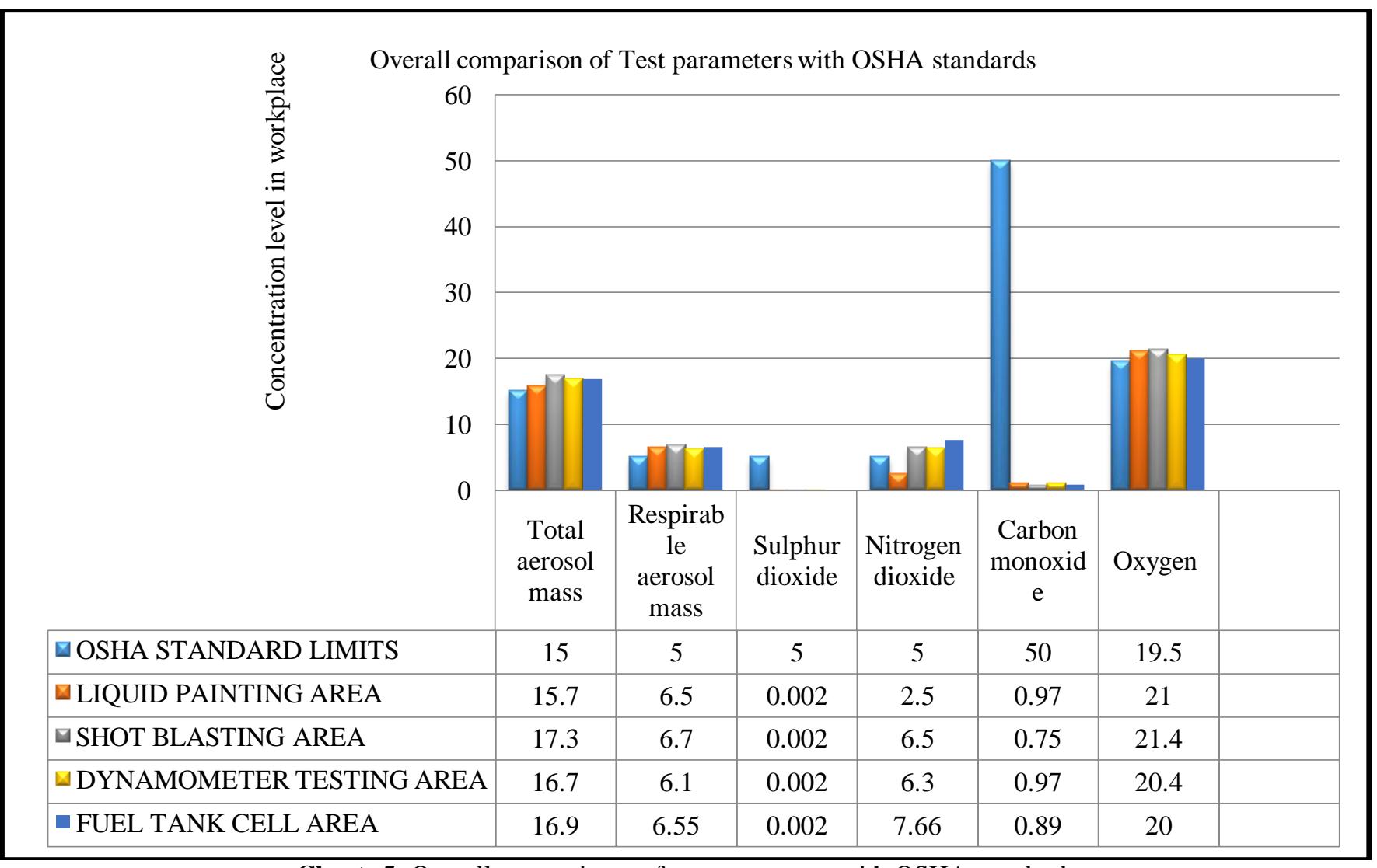

Chart -5: Overall comparisons of test parameters with OSHA standards

\section{CONCLUSIONS}

Criteria pollutant levels of TPM, RPM, $\mathrm{SO}_{2}, \mathrm{NO}_{2}$ and $\mathrm{CO}$ in the In-house ambient air of automobile industry are found to cross the limits in the single day per site random sampling, while Total Aerosol Mass level is also considerable at about $18.5 \mathrm{mg} / \mathrm{m}^{3}$ (maximum). It is likely that right now the levels of all the pollutants have crossed the limits at all the sites, but not revealed due to random nature of sampling. The values obtained at maximum level for each pollutant in the industry are given below. Nitrogen dioxide is 7.2, Respirable aerosol mass is 7.6 and Carbon monoxide and Sulphur dioxide are below the detection limit. The alarming situation will worsen further in future due to further addition of new operations in the industry. Preliminary random studies in all pollution prone areas of the industry irrespective of the grade to quantify the pollutants level will throw light on the range of pollutant level, cause-effect correlations, remedial strategies and priorities for the installation of continuous monitoring and control mechanism. Automobile industry is a stronger case for continuous monitoring of In-house ambient air quality in the areas: 1) Shot blasting, 2) Liquid painting, 3) Dynamometer testing is worthy considerations for selection of air quality monitoring in the industry. Continuous monitoring shall include all the six criteria pollutants ground level ozone, Carbon monoxide $\left(\mathrm{CO}_{2}\right)$, Sulfur dioxide $\left(\mathrm{SO}_{2}\right)$, Small particulates $\left(\mathrm{PM}_{10}\right)$, Nitrogen dioxide $\left(\mathrm{NO}_{2}\right)$, and the lead $(\mathrm{Pb})$. Suggestions on the basis of findings of the study. The suggestions are made the employees, contract workers including interested parties are at the health risk from ambient dust. Continuous monitoring and prevention of dust accumulation, arresting the dust at the source levels largely prevent re-suspension of particulates and will reduce the ambient particulate concentration.

\section{REFERENCES}

[1]. Balashanmugam, P., Ramanathan, A.R., Nehru kumar, V \&Elango, E. (2012). Ambient airquality studies on Cuddalore. International Journal of Environmental Sciences Volume.2No.3.

[2]. Balashanmugam, P., Ramanathan, A.R \& Nehru kumar, V. (2012). Assessment of ambient air quality in Chidambaram A South Indian town. Journal of Engineering Science and Technology Vol. 7, No.3.

[3]. Ediagbonya, T.F., Tobin, A.E., Legemah, M. (2013). Indoor and Outdoor Air Quality In Hospital Environment. Chemistry and Materials Research.Vol.3 No.10.

[4]. Gauvin, S. Reungoat, P., Cassadou, S. Dechen aux, J., Momas, J. Just, J. \&Zmirou, D. (2002).Contribution of indoor and outdoor environments to PM2.5 Personal exposure of children.VESTA Reading Sci Total Environ 297; 175-181.

[5]. Occupational Safety \& Health Standard Limits.

[6]. Patterson, E \&Eatough, D.J. (2000). Indoor/Pollutants: epidemiological implications in LindonUtah. J. Air Waste Manage Assoc 50; 103-110. 


\section{BIOGRAPHIES}

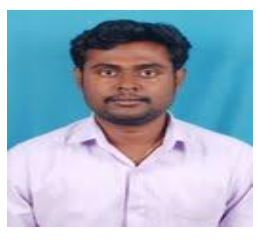

Mr. M.Arunkumar, Currently pursuing M.E. Industrial Safety Engineering at Knowledge Institute of Technology. He has completed his B.E. degree in Electronics and Communication Engineering.

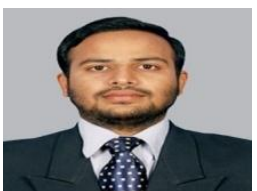

Dr. H. Abdul Zubar,received Ph.D. degree in from National Institute Of Technology, Trichy, Tamil Nadu, India, in 2014. Serving as an Associate Professorin Knowledge Institute of Technology. He has five years vast experience in teaching field and four years experience in industry has five years vast experience in teaching field and four years experience in field.

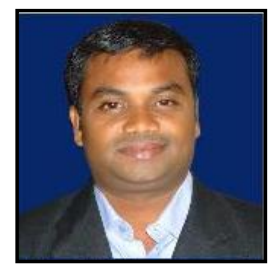

Dr. K. Visagavel received Ph.D. degree in Heat transfer and CFD from Anna University, Tamil Nadu, India, in 2009, and M.E. and B.E. degree in thermal power engineering and mechanical engineering from Annamalai University, Chidambaram, Tamil Nadu, India, in 1996 and 1998, respectively. From 1998 to 2009, he served as lecture, assistant professor, professor and Head in the Department of Mechatronics Engineering. Since April 2009, he has been a Professor, Head of the Mechanical Engineering department and Vice principal at Knowledge Institute of Technology. He is the author of three books, more than 41 articles. His research interests lie in thermal engineering. 